\title{
Penile Cancer pT4 TNM Finding v8
}

National Cancer Institute

\section{Source}

National Cancer Institute. Penile Cancer pT4 TNM Finding v8. NCI Thesaurus. Code C140068.

Penile cancer with tumor invading into adjacent structures (i.e., scrotum, prostate, pubic bone). (from AJCC 8th Ed.) 